Jurnal Inovasi Pembelajaran Fisika
(INPAFI)
Available online http://jurnal.unimed.ac.id/2012/index.php/inpafi
e-issn 2549-8258, p-issn 2337-4624

\title{
PENGARUH MODEL PEMBELAJARAN DISCOVERYTERHADAP KETERAMPILAN PROSES SAINS SISWA PADA MATERI POKOK GELOMBANG BUNYI DI KELAS XI SMA NEGERI 1 TANJUNG MORAWA T.P 2017/2018
}

\author{
Wahyuni Artika Ritonga dan Sabani \\ Jurusan Fisika FMIPA Universitas Negeri Medan \\ Jalan Williem Iskandar Psr. V Medan Estate, Medan, Indonesia, 20221 \\ writonga99@gmail.com,sabani@unimed.ac.id
}

Diterima : September 2018. Disetujui : Oktober 2018. Dipublikasi : Nopember 2018

\begin{abstract}
ABSTRAK
Penelitian ini bertujuan untuk mengetahui pengaruh model pembelajaran discovery terhadap keterampilan proses sains siswa pada materi pokok gelombang bunyi kelas XI di SMA N 1 Tanjung Morawa. Jenis penelitian ini adalah quasi experiment dengan group pre test-post test design. Populasi dalam penelitian ini adalah seluruh siswa kelas XI MIA SMA N 1 Tanjung Morawa terdiri dari 6 kelas berjumlah 192 siswa. Sampel penelitian terdiri dari dua kelas yaitu kelas XI MIA-1 sebagai kelas eksperimen berjumlah 33 siswa dan kelas XI MIA-3 sebagai kelas kontrol berjumlah 36 siswa. Instrumen yang digunakan adalah tes keterampilan proses sains yang terdiri dari 10 soal essay. Berdasarkan analisis data diperoleh bahwa ada pengaruh model pembelajaran discovery terhadap keterampilan proses sains siswa pada materi pokok gelombang bunyi di kelas XI SMA N 1 Tanjung Morawa.
\end{abstract}

Kata kunci : discovery, keterampilan proses sains, gelombang bunyi

\begin{abstract}
This study aims to determine the effect of discovery learning on student's science process skills in the subject matter sound wave in class XI SMA N 1 Tanjung Morawa. This research is a quasi experiment with group pre test-post test design. The population in the study was all students of class MIA SMA N 1 Tanjung Morawa consist of 6 classes totaling 192 students. The research sample consisted of two classes, a class XI MIA- 1 as class experiment totaling 33 students and XI MIA-3 as the control class totaling 36 students. The instrument used is student's science process skills test consists of 10 essay questions. Based on data analysis obtained that there was influence student's science process skills using discovery learning model in the subject matter of sound wave in class XI SMA N 1 Tanjung Morawa.
\end{abstract}

Keywords : science process skills, discovery, sound wave 
Wahyuni Artika Ritonga dan Sabani ; Pengaruh Model Pembelajaran Discovery terhadap Keterampilan Proses Sains Siswa pada Materi Pokok Gelombang Bunyi di Kelas XI SMA Negeri 1 Tanjung Morawa T.P 2017/2018

\section{PENDAHULUAN}

Perkembangan ilmu pengetahuan dan teknologi yang semakin pesat menuntut manusia untuk mengembangkan wawasan dan kemampuan di berbagai bidang. Perkembangan ilmu pengetahuan dan teknologi berkaitan erat dengan pendidikan. Undang-Undang Nomor 20 Tahun 2003 tentang Sistem Pendidikan Nasional menyatakan bahwa pendidikan adalah usaha sadar dan terencana untuk mewujudkan suasana belajar dan proses pembelajaran agar siswa aktif mengembangkan potensi diri untuk memiliki kekuatan spiritual keagamaan, pengendalian diri, kepribadian, kecerdasan, akhlak mulia, serta keterampilan yang diperlukan dirinya, masyarakat, bangsa dan negara.

Berbagai upaya telah dilakukan pemerintah dalam meningkatkan mutu pendidikan antara lain dengan melengkapi sarana dan prasarana, meningkatkan kualitas guru, serta penyempurnaan kurikulum yang menekan aspek-aspek yang bermuara pada peningkatan dan pengembangan kecakapan hidup yang dikenal dengan nama kurikulum 2013. Kurikulum 2013 adalah kurikulum pembelajaran berbasis sains. Pembelajaran berbasis sains atau lebih dikenal dengan pendekatan saintifik, merupakan proses pembelajaran yang dilaksanakan dengan dipandu skor-skor, prinsip-prinsip, atau kinerja ilmiah (Kemendikbud, 2013). Pendekatan saintifik dalam proses pembelajaran fisika dapat diterapkan melalui keterampilan proses sains.

Berdasarkan penjelasan tersebut, keterampilan proses sains (KPS) penting dimiliki oleh siswa untuk menentukan sikap dan tindakan yang benar pada saat dihadapkan dengan masalah-masalah yang terjadi di masyarakat (Aktamis dan Ergin, 2008). Permasalahan yang paling menonjol dalam pembelajaran sains adalah kurangnya pembelajaran yang dapat mengembangkan keterampilan proses sains siswa dan kurangnya pemahaman konsep yang berdampak pada hasil belajar siswa (Subagyo, dkk., 2009). Keterampilan proses sains yang masih rendah menuai banyak pertanyaan yang perlu dikaji lebih dalam lagi dari berbagai sisi, seperti kualitas guru saat mengajar, fasilitas praktikum yang kurang lengkap, dan ketidaksesuaian model pembelajaran.

Berdasarkan observasi dan wawancara yang dilakukan peneliti di SMA Negeri 1 Tanjung Morawa, bahwa model pembelajaran yang digunakan berpusat pada guru. Pembelajaran yang dilakukan oleh guru menggunakan metode ceramah, latihan soal dan penugasan secara individu menyebabkan siswa menjadi kurang aktif dalam pembelajaran. Osman dan Vebrianto (2013) menyatakan bahwa siswa sangat tidak tertarik dengan pembelajaran fisika yang berpusat pada guru, dengan kata lain guru sebagai pusat informasi, sehingga siswa hanya sebagai pendengar yang menyebabkan siswa kurang mampu untuk menguasai materi pembelajaran dan keterampilan proses sains yang tidak berkembang secara maksimal.

Siswa juga jarang melakukan praktikum karena kurangnya waktu untuk melaksanakan praktikum dan keterbatasan alat dan bahan praktikum. Materi pelajaran gelombang bunyi merupakan konsep dengan banyak aplikasi dalam kehidupan. Pembelajaran pada materi ini harus dipraktikumkan agar siswa lebih menguasai materi yang diajarkan. Hal ini tentunya akan memengaruhi kurangnya pengalaman belajar siswa dalam praktikum dan keterampilan proses sains siswa. Berdasarkan uraian dari beberapa masalah tersebut, ada beberapa model pembelajaran yang dapat digunakan untuk mengatasi masalah tersebut. Salah satunya yaitu model pembelajaran discovery. Discovery learning merupakan salah satu model pengajaran menurut teori kognitif 
yang berpengaruh dari Jerome Bruner. Bruner dalam Djiwandono (2002) menyarankan siswa harus belajar melalui kegiatan mereka sendiri dengan memasukkan konsep-konsep dan prinsipprinsip, dimana mereka didorong untuk mempunyai pengalaman dan melakukan eksperimen-eksperimen dan membiarkan mereka untuk menemukan prinsip-prinsip bagi mereka sendiri.

Model pembelajaran discovery menekankan pada pengalaman belajar aktif yang berpusat pada anak, anaknya menemukan ide-ide dan mengambil maknanya sendiri (Arends, 2012). Model pembelajaran discovery mengarahkan siswa pada kegiatan yang dapat mengembangkan keterampilan proses sains di mana siswa dibimbing untuk menemukan dan menyelidiki sendiri tentang suatu konsep sains sehingga pengetahuan dan keterampilan yang dimiliki siswa bukan hasil mengingat seperangkat fakta melainkan hasil temuan sendiri.

Penelitian mengenai model pembelajaran discovery sudah pernah diteliti oleh peneliti sebelumnya. Berdasarkan penelitian yang dilakukan oleh Ningsih (2015) menunjukkan bahwa pendekatan discovery berpengaruh terhadap keterampilan proses sains siswa pada kelas eksperimen dibandingkan dengan menggunakan model pembelajaran konvensional. (Kumalasari, dkk., 2015) juga menunjukkan bahwa model discovery learning berpengaruh terhadap keterampilan proses sains siswa dan hasil belajar siswa pada mata pelajaran IPA. Berdasarkan latar belakang di atas, maka peneliti berkeinginan melakukan penelitian untuk mengetahui pengaruh model pembelajara discovery terhadap keterampilan proses sains siswa pada materi pokok gelombang bunyi di SMA Negeri 1 Tanjung Morawa T.P 2017/2018.

\section{METODE PENELITIAN}

Penelitian dilaksanakan di SMA Negeri 1 Tanjung Morawa T.P 2017/2018. Populasi dalam penelitian yaitu seluruh siswa kelas XI MIA SMA Negeri 1 Tanjung Morawa pada semester II T.P 2017/2018 berjumlah 192 orang, terdiri dari 6 kelas. Sampel penelitian terdiri dari dua kelas yaitu kelas XI MIA-1 sebagai kelas eksperimen menggunakan model pembelajaran discovery dan kelas XI MIA-3 sebagai kelas kontrol menggunakan model pembelajaran konvensional.

Jenis penelitian ini adalah quasi experiment atau eksperimen semu dengan rancangan group pre test-post test design dapat dilihat pada Tabel 1.

Tabel 1. Group Pre test-Post test Design

\begin{tabular}{|l|c|c|c|}
\hline Kelas & Pretes & Perlakuan & Postes \\
\hline Eksperimen & $\mathrm{T}_{1}$ & $\mathrm{X}$ & $\mathrm{T}_{2}$ \\
\hline Kontrol & $\mathrm{T}_{1}$ & $\mathrm{Y}$ & $\mathrm{T}_{2}$ \\
\hline
\end{tabular}

Keterangan :

$\mathrm{T}_{1} \quad$ : tes awal

$\mathrm{T}_{2} \quad$ : tes akhir

$\mathrm{X}$ : penerapan model pembelajaran discovery

$\mathrm{Y}$ : penerapan pembelajaran konvensional

Peneliti memberikan pre test pada kelas eksperimen dan kelas kontrol. Instrumen yang digunakan pada penelitian ini adalah tes keterampilan proses sains siswa berjumlah 10 butir soal dalam bentuk essay. Data pre test keterampilan proses sains siswa yang diperoleh dianalisis dengan uji hipotesis dua pihak untuk mengetahui kemampuan awal siswa pada kedua kelas dengan syarat harus dilakukan uji normalitas dan homogenitas.

Peneliti kemudian melakukan pembelajaran dengan menggunakan model pembelajaran discovery pada kelas eksperimen dan model pembelajaran konvensional pada kelas kontrol. Peneliti 
Wahyuni Artika Ritonga dan Sabani ; Pengaruh Model Pembelajaran Discovery terhadap Keterampilan Proses Sains Siswa pada Materi Pokok Gelombang Bunyi di Kelas XI

SMA Negeri 1 Tanjung Morawa T.P 2017/2018

memberikan post test setelah diberikan perlakuan yang berbeda pada kedua kelas. Data post test dianalis dengan melakukan uji normalitas, uji homogenitas, dan uji hipotesis satu pihak untuk mengetahui perbedaan hasil akhir apakah ada pengaruh model pembelajaran discovery terhadap keterampilan proses sains siswa.

\section{HASIL DAN PEMBAHASAN}

\section{a. Hasil Penelitian}

Data penelitian ada dua macam yaitu tes dan observasi keterampilan proses sains. Hasil pre test siswa kelas eksperimen dan kelas kontrol ditunjukkan pada Gambar 1.

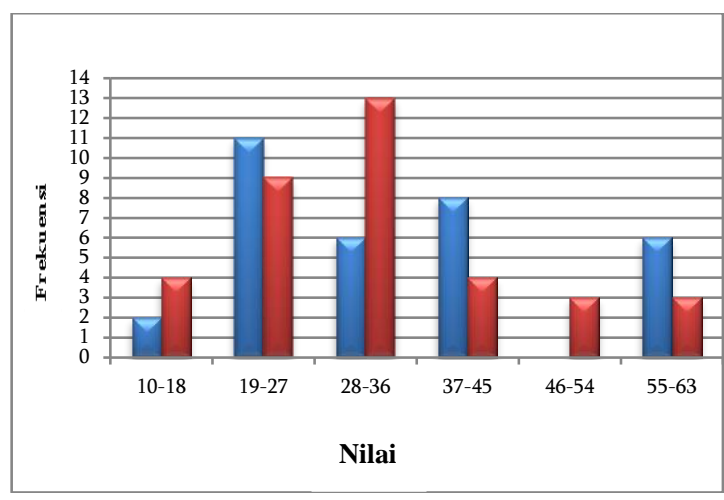

Gambar 1. Hasil Pre test

Gambar 1 menunjukkan bahwa frekuensi tertinggi dari hasil pre test siswa pada kedua kelas berada pada rentang nilai yang rendah. Rata-rata pre test siswa pada kelas eksperimen dan kelas kontrol menunjukkan bahwa kemampuan awal siswa sama atau tidak ada perbedaan yang signifikan, di mana rata-rata pre test pada kelas eksperimen 34,54 dan kelas kontrol 32,29 .

Hasil post test siswa kelas eksperimen dan kelas kontrol ditunjukkan pada Gambar 2 dan Gambar 3.

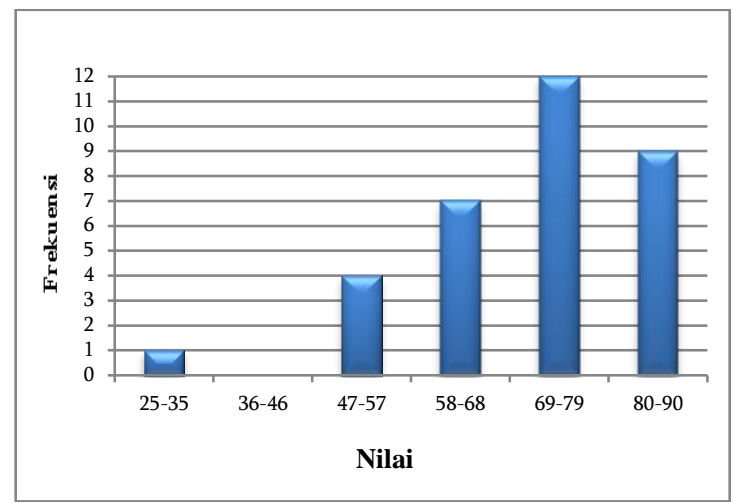

Gambar 2. Hasil Post test Kelas Eksperimen

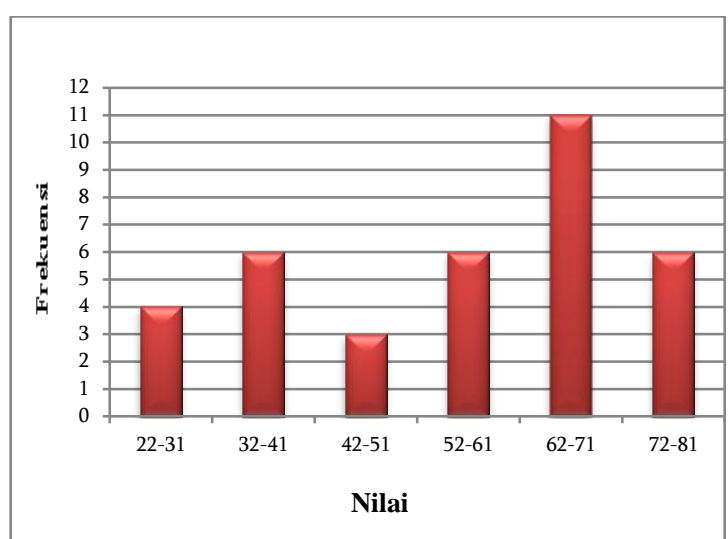

Gambar 3. Hasil Post test Kelas Kontrol

Gambar 2 dan 3 menunjukkan bahwa perbedaan hasil post test kelas eksperimen dan kelas kontrol, di mana perolehan tertinggi siswa pada kelas eksperimen pada rentang nilai 80-90 sedangkan pada kelas kontrol pada rentang nilai 72-81. Rata-rata post test siswa pada kelas eksperimen menunjukkan perbedaan yang signifikan dengan rata-rata post test siswa pada kelas kontrol, di mana rata-rata post test pada kelas eksperimen 71,81 dan kelas kontrol 54,16.

Peningkatan keterampilan proses sains siswa pada kelas eksperimen dapat dilihat melalui hasil observasi keterampilan proses sains siswa yang ditunjukkan pada Tabel 2. 
Tabel 2. Hasil Observasi KPS Siswa

\begin{tabular}{|l|c|c|c|}
\hline \multirow{2}{*}{ Aspek KPS } & \multicolumn{3}{|c|}{ Nilai pada Pertemuan } \\
\cline { 2 - 4 } & I & II & III \\
\hline Mengamati & 62 & 83 & 87 \\
\hline $\begin{array}{l}\text { Merumuskan } \\
\text { hipotesis }\end{array}$ & 54 & 66 & 72 \\
\hline Memprediksi & 55 & 66 & 72 \\
\hline $\begin{array}{l}\text { Menemukan pola } \\
\text { dan hubungan }\end{array}$ & 60 & 77 & 77 \\
\hline $\begin{array}{l}\text { Merancang } \\
\text { percobaan }\end{array}$ & 61 & 66 & 78 \\
\hline $\begin{array}{l}\text { Berkomunikasi } \\
\text { secara efektif }\end{array}$ & 78 & 78 & 83 \\
\hline $\begin{array}{l}\text { Mengukur dan } \\
\text { menghitung }\end{array}$ & 45 & 56 & 61 \\
\hline
\end{tabular}

\section{b. Pembahasan}

Penelitian diawali dengan

melakukan tes awal (pre test) pada kedua kelas sampel,di mana rata-rata pre test pada kelas eksperimen 34,54 dan kelas kontrol 32,29 menunjukkan bahwa kemampuan awal siswa sama atau tidak ada perbedaan yang signifikan. Berdasarkan uji normalitas diperoleh Lo $=0,1519$ dan $\mathrm{L}_{\text {tabel }}=0,1542$ pada kelas eksperimen dan Lo $=0,1390$ dan $\mathrm{L}_{\text {tabel }}=0,1476$ pada kelas kontrol sehingga dapat disimpulkan Lo $<\mathrm{L}_{\text {tabel }}$ maka data pre test kedua kelas berdistribusi normal. Berdasarkan uji homogenitas diperoleh bahwa $F_{\text {hit }}=1,20$ dan $F_{\text {tabel }}=1,72$, sehingga $F_{\text {hit }}<F_{\text {tabel }}(1,20<1,72)$ maka data pre test kedua kelas mempunyai varians yang sama.

Kemudian diberikan perlakuan yang berbeda, di mana pada kelas eksperimen dilakukan pembelajaran menggunakan model pembelajaran discovery dan pada kelas kontrol dilakukan pembelajaran menggunakan model pembelajaran discovery. Setelah dilakukan pembelajaran, kedua kelas melakukan tes akhir (post test). Rata-rata post test siswa pada kelas eksperimen menunjukkan perbedaan yang signifikan dengan rata-rata post test siswa pada kelas kontrol, di mana rata-rata post test pada kelas eksperimen 71,81 dan kelas kontrol 54,16.

Berdasarkan data post test yang diperoleh menunjukkan bahwa keterampilan proses sains siswa pada kelas eksperimen menggunakan model pembelajaran discovery lebih tinggi dibanding pada kelas kontrol menggunakan model pembelajaran konvensional. Berdasarkan uji normalitas Lo $=0,0955$ dan $\mathrm{L}_{\text {tabel }}=0,1542$ pada kelas eksperimen dan Lo $=0,1463$ dan $\mathrm{L}_{\text {tabel }}=$ 0,1476 pada kelas kontrol sehingga dapat disimpulkan Lo $<\mathrm{L}_{\text {tabel }}$ maka data pre test kedua kelas berdistribusi normal. Berdasarkan uji homogenitas diperoleh bahwa $F_{\text {hit }}=1,71$ dan $F_{\text {tabel }}=1,80$, sehingga $F_{\text {hit }}<F_{\text {tabel }}(1,71<1,80)$ maka data post test kedua kelas mempunyai varians yang sama.

Berdasarkan pengujian hipotesis yang telah dilakukan menunjukkan bahwa ada pengaruh model pembelajaran discovery terhadap keterampilan proses sains siswa pada materi pokok gelombang bunyi di kelas XI SMA Negeri 1 Tanjung Morawa. Adanya pengaruh disebabkan karena kelebihan pada model pembelajaran discovery yaitu sebuah pembelajaran dimana siswa mengkontruksi pengetahuan mereka sendiri secara aktif dalam mengadakan suatu praktikum untuk menemukan sebuah prinsip dari hasil praktikum tersebut (Joolingen, 1999). Siswa dibentuk dalam kelompok dan diberikan kesempatan melakukan percobaan untuk menemukan jawaban dari materi yang diberikan, dan jawaban tersebut diungkapkan dalam lembar kerja peserta didik.

Siswa secara berkelompok melakukan pengamatan dan mencatat hasil penemuannya. Pada saat melakukan percobaan, keterampilan proses sains siswa mulai berkembang dalam proses pembelajaran discovery. Pembelajaran fisika 
Wahyuni Artika Ritonga dan Sabani ; Pengaruh Model Pembelajaran Discovery terhadap Keterampilan Proses Sains Siswa pada Materi Pokok Gelombang Bunyi di Kelas XI SMA Negeri 1 Tanjung Morawa T.P 2017/2018

menggunakan model pembelajaran discovery terbukti melatih siswa dalam mengembangkan keterampilan proses sains sehingga hakikat sains sebagai proses dan produk dalam pembelajaran fisika dapat terlaksana secara maksimal. Hal ini sesuai dengan pendapat Akinbobola dan Afolabi (2010) bahwa model pembelajaran discovery sebaiknya digunakan guru untuk mengembangkan keterampilan proses sains siswa. Eva, dkk., (2016) berpendapat bahwa penerapan model pembelajaran discovery berpengaruh signifikan keterampilan sains siswa.

Isnaningsih dan Bimo (2013) juga memperoleh bahwa penerapan LKS discovery berorientasi keterampilan proses sains dapat meningkatkan hasil belajar IPA siswa SMP. Hal yang sama ditemukan oleh Widiadnyana, dkk., (2014) berpendapat bahwa terdapat perbedaan nilai rata-rata sikap ilmiah secara signifikan antara kelompok siswa yang belajar dengan discovery learning dengan model pengajaran langsung.

Proses belajar mengajar di kelas XI MIA-1 sebagai kelas eksperimen melakukan tahap-tahap model pembelajaran discovery. Tahap-tahap model pembelajaran discovery menurut Hosnan (2014) yaitu stimulation, problem statment, data collection, data processing, verification, dan generalization. Siswa berpartisipasi aktif dalam melakukan proses discovery untuk menemukan konsepkonsep yang diberikan pada materi gelombang bunyi. Siswa aktif bertanya maupun menjawab pertanyaan, melakukan percobaan dan berdiskusi selama pembelajaran berlangsung.

Contohnya, pada stimulation adalah tahap pertama dalam model pembelajaran discovery di mana peneliti menayangkan video permainan telepon kaleng. Proses discovery yang terjadi adalah siswa menemukan bahwa benang pada permainan telepon kaleng dapat menghantarkan bunyi.
Aspek keterampilan proses sains yang dilatih pada tahap stimulation adalah aspek mengamati.

Problem statement adalah tahap kedua di mana peneliti menanyakan kepada siswa mengenai hubungan konsep karakteristik bunyi dengan permainan telepon kaleng tersebut. Proses discovery yang terjadi adalah siswa menemukan masalah yang diberikan. Aspek keterampilan proses sains yang dilatih pada tahap problem statment adalah aspek merumuskan hipotesis dan memprediksi.

Data collection adalah tahap ketiga di mana peneliti mengajak siswa melakukan percobaan fenomena bunyi sebagai gelombang mekanik untuk menemukan jawaban dari masalah yang diberikan. Proses discovery yang terjadi adalah siswa menemukan konsep bahwa salah satu karakteristik bunyi sebagai gelombang mekanik. Aspek keterampilan proses sains yang dilatih pada tahap data collection adalah aspek mengukur dan menghitung, dan merancang percobaan. Data processing adalah tahap keempat di mana peneliti mengajak siswa untuk mengolah data yang telah diperoleh pada percobaan. Proses discovery yang terjadi adalah siswa menemukan konsep hubungan karakteristik bunyi dengan permainan telepon kaleng.

Verification adalah tahap kelima di mana peneliti mengajak siswa mendiskusikan kembali data yang telah diolah apakah sesuai dengan teori yang ada pada sumber atau buku yang lain dan mempresentasikan hasil diskusi tersebut. Proses discovery yang terjadi pada tahap ini adalah siswa menemukan jawaban atas masalah yang diberikan. Aspek keterampilan proses sains yang dilatih pada tahap data processing dan verification adalah aspek menemukan pola dan hubungan dan berkomunikasi secara efektif. Generalization adalah tahap akhir di mana peneliti mengajak 
siswa untuk menyimpulkan poin-poin penting.

Proses belajar mengajar di kelas XI MIA-3 sebagai kelas kontrol hanya mendengar dan mencatat materi yang diberikan oleh peneliti. Peneliti menyampaikan materi dengan ceramah dan memberikan tugas individu kepada siswa. Hampir tidak ada siswa yang bertanya maupun menjawab pertanyaan yang diberikan selama pembelajaran berlangsung. Model pembelajaran konvensional yang dilakukan pada kelas kontrol cenderung membosankan sehingga siswa kurang aktif dalam pembelajaran.

Penelitian juga melakukan observasi keterampilan proses sains siswa pada kelas eksperimen untuk melihat peningkatan keterampilan proses sains siswa setiap pertemuan. Keterampilan proses sains memiliki 7 aspek yaitu mengamati, merumuskan hipotesis, memprediksi, menemukan pola dan hubungan, komunikasi secara efektif, merancang percobaan serta mengukur dan menghitung. Aspek berkomunikasi secara efektif memiliki nilai tertinggi pada pertemuan I. Hal itu dikarenakan pembelajaran yang dilakukan melatih siswa untuk berkomunikasi secara efektif, di mana siswa secara berkelompok melakukan diskusi, presentasi, dan memberikan pendapat antar kelompok. Aspek mengamati memiliki nilai tertinggi pada pertemuan II dan pertemuan III. Hal itu dikarenakan pembelajaran yang dilakukan melatih siswa mengamati dengan baik. Contohnya, pada percobaan fenomena gelombang bunyi, siswa mengamati perbedaan dua keadaan fenomena bunyi yaitu pada keadaan tertutup (di dalam toples) dan terbuka untuk menemukan konsep dari karakteristik gelombang bunyi tersebut. Berdasarkan data tersebut, diperoleh bahwa semua aspek keterampilan proses sains siswa mengalami peningkatan dalam setiap pertemuan. Hal itu menunjukkan bahwa setiap aspek keterampilan proses sains dilatih pada proses pembelajaran discovery sehingga mengalami peningkatan untuk setiap pertemuan.

Setelah melakukan penelitian, kendala yang dihadapi peneliti yaitu sulit mengatur posisi duduk siswa dan kurang terlatihnya siswa menggunakan alat dan bahan percobaan. Peneliti selanjutnya diharapkan merancang terlebih dahulu posisi duduk siswa dan melakukan simulasi penggunaan alat dan bahan percobaan.

\section{KESIMPULAN DAN SARAN}

Berdasarkan hasil penelitian dan analisis data yang diperoleh maka dapat disimpulkan ada pengaruh model pembelajaran discovery terhadap keterampilan proses sains siswa pada materi pokok gelombang bunyi di kelas XI SMA Negeri 1 Tanjung Morawa. Adapun saran yang didapat peneliti dari penelitian yang dilakukan adalah guru sebaiknya merancang terlebih dahulu posisi duduk siswa dan melakukan simulasi penggunaan alat dan bahan percobaan.

\section{DAFTAR PUSTAKA}

Akinbobola dan Afolabi. 2010. Constructivist Practices Through Guided Discovery Approach : The Effect on Student's Cognitive Achievement in Nigerian Senior Secondary School Physics. Eurasian Journal of Physics and Chemistry Education 2(1) : 16-25.

Aktamis dan Ergin. 2008. The Effect of Scientific Process Skills Education on Students Scientific Creativity, Science Attitudes and Academic Achievements. Journal Asia Pacific Forum on Science Learning and Teaching 9(1) : 1-21. 
Wahyuni Artika Ritonga dan Sabani ; Pengaruh Model Pembelajaran Discovery terhadap Keterampilan Proses Sains Siswa pada Materi Pokok Gelombang Bunyi di Kelas XI SMA Negeri 1 Tanjung Morawa T.P 2017/2018

Arends, R. I. 2012. Learning to Teach. Yogyakarta : Pustaka Pelajar.

Djiwandono, S. E. 2002. Psikologi Pendidikan. Jakarta : Grasindo.

Eva, S., Mohamad Jamhari., Samsurizal. 2016. Pengaruh Model Pembelajaran Discovery terhadap Keterampilan Proses dan Hasil Belajar Siswa Kelas VIII tentang IPA SMP Advent Palu. Jurnal Sains dan Teknologi Tadulako $5(3): 36-41$.

Hosnan, M. 2014. Pendekatan Saintifik dan Konstektual dalam Pembelajaran Abad 21. Bogor : Penerbit Ghalia Indonesia.

Isnaningsih dan Bimo. 2013. Penerapan Lembar Kegiatan Siswa (LKS) Discovery Berorientasi Keterampilan Proses Sains Untuk Meningkatkan Hasil Belajar IPA. Jurnal Pendidikan IPA Indonesia 2(2) : 134-141.

Joolingen, W. V. 1999. Cognitivle Tools for Discovery Learning, Intelligence In Education (IJAIED). International Journal of Artificial Intelligence in Education 10(1) : 385-397.

Kemendikbud. 2013. Kerangka Dasar Kurikulum 2013. Jakarta : Kementrian Pendidikan dan Kebudayaan Direktorat Jenderal Pendidikan Dasar.

Kumalasari, D., Sudarti., Lesmono. 2015. Dampak Model Discovery Learning terhadap Keterampilan Proses Sains dan Hasil Belajar IPA-Fisika Siswa di MTs Negeri 1 Jember. Jurnal Pendidikan Fisika 4(1) : 80-86.

Ningsih, R. 2015. Pengaruh Pendekatan Discovery terhadap Keterampilan
Proses Sains dan Tanggungjawab Siswa Materi Saling Ketergantungan dalam Ekosistem Kelas VII SMP Muhammadiyah Palangka Raya Tahun Ajaran 2014/2015. Jurnal EduSains 3(2) : 149-160.

Osman dan Vebrianto. 2013. Fostering Science Process Skills and Improving Achievement Through The Use of Multiple Media. Journal of Baltic Science Education 12(2) : 191-204.

Subagyo, Y., Wiyanto., Marwoto. 2009. Pembelajaran dengan Pendekatan Keterampilan Proses Sains untuk Meningkatkan Penguasaan Konsep Suhu dan Pemuaian. Jurnal Pendidikan Fisika Indonesia 5(1) : 42-46.

Widiadnyana, I. W., Sadia., Suastra. 2014. Pengaruh Model Discovery Learning terhadap Pemahaman Konsep IPA dan Sikap Ilmiah Siswa SMP. Jurnal Universitas Pendidikan Ganesha 4(1) : 1-13. 